\title{
Chemical, Colour and Strength Changes of Eco-friendly Hot Oil Treatment on 15 Year-old Cultivated Acacia Hybrid
}

\author{
Razak Wahab ${ }^{1}$, Othman Sulaiman ${ }^{2}$, Izyan Khalid ${ }^{1}$, \\ Mohd Sukhairi Mat Rasat ${ }^{1} \&$ Mahmud Sudin ${ }^{3}$ \\ ${ }^{1}$ Faculty of Earth Science, Universiti Malaysia Kelantan, Campus Jeli, 17600 Jeli Kelantan, Malaysia \\ E-mail:razak@umk.edu.my \\ ${ }^{2}$ School Industrial Technology, Universiti Sains Malaysia, 11800 Penang, Malaysia \\ ${ }^{3}$ School International Tropical Forestry, Universiti Malaysia Sabah, \\ 88999, Kota Kinabalu, Sabah, Malaysia
}

\begin{abstract}
The chemical, colour and strength properties of thermally modified cultivated 15-year-old Acacia hybrid were investigated. Logs of $A$. hybrid were harvested and cut at the bottom, middle and top sections. The wood later underwent hot oil thermal modification using palm oil at temperatures $180^{\circ} \mathrm{C}, 200^{\circ} \mathrm{C}$ and $220^{\circ} \mathrm{C}$ for 30,60 and 90 min. Untreated wood was used as control. The hot oil thermal modification process caused some features changed in the chemical composition, colour appearances and strength properties of $A$. hybrid wood. Parameters such as temperatures and treatment time were closely monitored as they influence the chemical, colour and strength changes in the treated wood. Temperatures of $180^{\circ} \mathrm{C}, 200^{\circ} \mathrm{C}$ and $220^{\circ} \mathrm{C}$, and treatment time of $1 \mathrm{hr}$, 2 hrs. and 3 hrs. were used in the study. The degradation in holocellulose, cellulose, and hemicellulose contents was recognized when acacia woods were exposed to oil thermally modified process. Holocellulose and celulose degraded with the increasing of treatment temperature and duration of heating exposure, while lignin showed the increment in content through this treatment. The colour changes in the sapwood and heartwood were measured using the Minolta Chroma-meter CR-310 and the results are presented according to the CIE $L * a * b *$ colour co-ordinates system. The results show that temperature at certain treatment time enhanced and darkened the treated wood. The colour of the treated sapwood can be enhanced to match the colour of the natural $A$. hybrid heartwood. The strength properties of the oil heat treated $A$. hybrid wood decreases in values of both MOR and MOE throughout the treatment process. The decreases in values were influenced by temperature and duration of the treatment.
\end{abstract}

Keywords - Cultivated Acacia hybrid, thermal modification wood, colour changes, chemical changes, and strength reductions.

\section{INTRODUCTION}

Forest plantation has become an important source of raw materials procurement to the current wood-based industry in the world. This is mainly due to the scarcity in obtaining supply from the natural forest. The sensitivity of the consumers in Europe and North America about logging activities of naturally grown species from tropical rainforest has further aggregate the problem. Plantation forestry rotations which are shorter than of natural stands provide attractive investments for government and private sectors to fulfill the needs of the timber industries and, at the same time, conserve the natural forest from continuously being depleted by logging activities.

Acacia was chosen as a plantation species based on its quick growth, easy adaptability to local soil condition and the high quality of wood it produced. Acacia is also highly sought and appreciated for its quality in producing exquisite furniture with lasting values at affordable cost. The furniture is valued mostly based on its strength, durability and aesthetic value such as grain orientation and colours. The hot oil thermal modification process seems to be a suitable modification because of its competitive advantage as an environment friendly process, since it does not require the uses of chemicals preservative [1]. Most woods treatment used preservative which mostly have heavy metals and discharge toxin to the environment. Many developed countries have totally banned the use of Chrome-copper Arsenic (CCA) in their woody materials [2]. In recent years, advances in environmental awareness and the effects policies which support the use of renewable resources and environment-friendly chemicals have resulted in high interest in non-biocides. As such a lot of effort has been put 
into developing new chemical wood preservatives. Another environment friendly technique for wood modification is the use of biogradable substances in wood protection [3].

This paper focused on the changes that occurred in the main chemical components of an oil heat treated cultivated $A$. hybrid and their effects on the strength of the wood. Chemical constituents, colour changes and strength properties are parameters that influenced durability, appearances and stability of the wood. The results of this study will be beneficial in improving the technologies in treating acacia wood for the industry.

\section{MAterials AND Methods}

Materials: Logs of 15-year-old $A$. hybrid trees were harvested from the Sabah Forest Development Authority in Kinarut, Kota Kinabalu, Sabah, Malaysia. The trees were selected based on their good physical appearances, diameter ranging from between 250 to $300 \mathrm{~mm}$ and long straight bole with minimum branches. The logs were cut and segregated into three height sections, namely, the bottom, middle and top, corresponding to 50,30 and $20 \%$ of the merchantable height respectively. Blocks of $600 \mathrm{~mm}$ long were cut from the middle of each section. The wood blocks were then transported to Universiti Malaysia Sabah (UMS) for further processing and subsequent testing. The study was conducted in UMS from Jan. 2010 to Oct. 2012.

Sample preparation: The wood blocks were air dried at room temperature for about a month to reduce the moisture to equivalent moisture content $(15 \%)$ and to remove stresses in them. After drying, the wood blocks were planed into sizes of $300 \mathrm{~mm} \times 100 \mathrm{~mm} \times 25 \mathrm{~mm}$ (length $\times$ width $\times$ thickness) for the oil heat treatment process. These samples were mixture of sapwood and heartwood. They were then oil heat treated using palm oil as the heating medium. Untreated wood were used as control for comparison purposes.

Hot oil thermal modification process: $A$. Hybrid samples were hot oil treated in a locally designed heat treatment machine's stainless steel tank. Palm oil was used as the heating medium. The temperatures of the oil and the wood samples were control through a control panel located on the out-side of the tank. An electric generator was used to generate heat. Prior to treatment, the wood samples were stabilized to $12 \%$ moisture content in a conditional chamber set at $65 \%$ relative humidity and temperature $25{ }^{\circ} \mathrm{C}$. Eighty (80) woods were prepared prior to the treatment The weight of the woods were recorded before and after treatment to determine weight loss caused by the treatment. The tank was filled with the oil until it reached three quarters full. Treatment temperature was set at $180^{\circ} \mathrm{C}, 200^{\circ} \mathrm{C}$ and $220^{\circ} \mathrm{C}$ for 30, 60 and $90 \mathrm{~min}$. The samples were initially placed into hot oil at $80^{\circ} \mathrm{C}$ and real treatment time started when the oil bath reached target temperature. The temperatures were recorded every $10 \mathrm{~min}$ respectively. After each treatment period, the wood samples were removed from the tank and wiped with a clean cloth to avoid excessive oil seeping into wood tissues. The samples were then cooled and later conditioned in a conditioning chamber at $20 \pm 2{ }^{\circ} \mathrm{C}$ and $65 \pm$ $5 \%$ relative humidity before reweighing. The wood samples were later cut into various sizes for respective testing for chemical analysis and strength tests. The procedure outlines by Razak et al. [1] were followed for the wood treatment and testing.

\section{Chemical Properties}

Chemical Analysis: The evaluations of chemical evaluated in the treated wood were the alcohol-toluene solubility, holocellulose, alpha-cellulose and klason lignin. All chemical analysis tests were conducted separately for heartwood and sapwood. The total amounts of the chemical constituent were calculated based on the sapwood or heartwood ratios. Evaluation of chemical analysis was conducted using TAPPI T203 om-99 [4] and TAPPI T222 om-02 [5] standards.

Sample Preparation: Wood samples were divided into the heartwood and sapwood in the study of the chemical composition. The woods were chipped for grinding purposes. Wood were ground into powder with Willey's mill in order to pass BS 40-mesh sieve and retained on a BS 60mesh sieved. The grinded samples were then dried in for 7 days until the MC is in equilibrium with the surrounding before they were chemically analyzed. A small weighing bottle previously cleaned and dried in an oven was weighed on an analytical balance to the nearest $0.01 \mathrm{~g} .2 \mathrm{~g}$ air-dried sawdust was placed in the weighing bottle and reweigh to the nearest $0.01 \mathrm{~g}$. The sample was then dried in an oven at $103 \pm 2{ }^{\circ} \mathrm{C}$ for 3 hours with the cover off. Then the bottle was removed and placed in a desiccator for $15 \mathrm{~min}$ to let it cool before weighing it. The moisture content of the sawdust was determined.

Colour Measurement of Heat Treated Samples: The colour measurement were taken before and after the wood samples had completed the hot oil thermal modification process at temperatures $180^{\circ} \mathrm{C}, 200^{\circ} \mathrm{C}, 220^{\circ} \mathrm{C}$ for treatment time of 30,60 , and 90 minutes respectively. Prior to this, the surfaces on the woods to be measured were marked before the heat treatment process. This was done to ensure the wood surface measured were consistent throughout the process. By using pencil, the marked point was done by $2 \mathrm{x}$ $2 \mathrm{~cm}$ at the cross-sectional surface of each sapwood and heartwood. This section was regarded as the most representative area for revealing the colour difference of sample [6]. Samples for the colour measurement were taken at the middle of the sapwood and heartwood in the cross sections of the $A$. hybrid at each portion height. The samples were sanded down slightly for about $3 \mathrm{~mm}$ with P100 sandpaper and brushed cleanly to minimize the risk of variation colour values cause by differences in surface structure. The measurements of colour were determined according to CIE $\mathrm{L}^{*} \mathrm{a} * \mathrm{~b}^{*}$ [7] system for providing more accurate and objective colour determination. Changes in colour of the wood surfaces due to treatment were measured by using a Minolta Chroma Meter CR-10. These measurements were only done on clear wood surfaces. The sensor head was $8 \mathrm{~mm}$ in diameter. The colour reader measures the colour difference on the surface of wood specimens between two colours which that before and after treatment. The results were presented according to the CIE 
$L^{*} a^{*} b^{*}$ colour co-ordinates system base on the D65 light source with the reflection spectrum was measured in the 400 $-700 \mathrm{~nm}$ regions. These values were used to calculate the colour change as a function of thermal treatment.

Strength Properties [Static Bending (Modulus of Rupture and Modulus of Elasticity)]: Evaluation of static bending of the wood was conducted in accordance with ASTM D4761 (1999) [8] standard. A Universal Testing Machine located in Forest Research Center, Sandakan, Sabah, was used for bending testing. The dimensions of wood samples for static bending test were $20 \times 20 \times 300$ $\mathrm{mm}$. The specimen was supported on a span of $280 \mathrm{~mm}$ and the force applied at mid-span using a loading head. The rate of loading was $6.6 \mathrm{~mm} / \mathrm{min}$. Wood were loaded on the radial surface. The tests were stopped when the wood started to break. The proportional limit and ultimate load and deflection were recorded, and the MOE and MOR were calculated automatically by the computer connected to the machine.

\section{RESUlt AND DISCUSSION}

\section{Chemical Properties}

Table 1 showed the chemical composition of the treated acacia wood before and after undergoing the hot oil treatment process. Both the control sapwood and heartwood had the highest chemical compositions of holocellulose and cellulose when compared with the oil heat treated wood at various treatment temperature and time. The results clearly showed that the changes of chemical components compositions occurred when the wood were treated at higher temperature and duration [9]. At temperature above $180^{\circ} \mathrm{C}$, the hot oil treated wood experiences the loss of polysaccharide material [10]. For treated sapwood, holocellulose contents varied between $63.1 \%$ and $70.8 \%$ while cellulose between $37.7 \%$ and $46.2 \%$, with hemicelluloses contents varied between $23 \%$ and $26.1 \%$ and lignin between $19.2 \%$ and $24.9 \%$ at $180-220^{\circ} \mathrm{C}$ with 30 to 90 minutes treatments. On the other hand, holocellulose contents for treated heartwood varied between $64 \%$ and $71.7 \%$, cellulose between $38.1 \%$ and $47.8 \%$, hemicelluloses contents varied between $23.2 \%$ and $26.2 \%$ with and lignin between $22.4 \%$ and $27.0 \%$ at $180-220^{\circ} \mathrm{C}$ with 30 to 90 minutes treatments.

Holocellulose: Slight reduction on the holocellulose contents in the treated sapwood and heartwood occurred with the increament in of treatment temperature and time in comparison to both untreated sapwood and heartwood. The holocellulose contents ranged between 63.1 to $70.8 \%$ for sapwood and 64.0 to $71.7 \%$ for heartwood depending on the temperature and duration applied. Studies by Inari et al. [11] and Boonstra and Tjeerdsma [12] also reported similar observations. The holocellulose content of beech and pine decreases between $50 \%$ and $60 \%$ after heat treatment [11]. While Boonstra and Tjeerdsma [12] found that holocellulose content of heat treated Scots pine decreased between $79.7 \%$ and $63.3 \%$. The decreases in the holocellulose content occurred when the wood were heated at a temperature above $100^{\circ} \mathrm{C}[10]$. The content decrease is associated with the loss of cellulose and hemicellulose during the process.

Cellulose: Cellulose content determined for both wood types after heat treatment were between $80-98 \%$ for sapwood, while the values for heartwood were between $78-97 \%$. The results showed that minor degradation of celluloses occurred when the wood treated at $180^{\circ} \mathrm{C}$ for $30 \mathrm{~min}$ and continue to decrease with the increase in treatment temperature. Cellulose is more resistant to hydrolysis than hemicelluloses, pectins and starch, and it has generally a more regular and crystalline structure with considerably higher molecule weight [13]. From the analysis of molecule size of cellulose in heat treatment by using intrinsic viscosity measurement, it showed that heat treatment results in a considerable reduction in molecule size of cellulose. As stated by Yildz et al. [14], crystalline structure of cellulose is not changed or even can improve up to a certain temperature, which may be as high as $200^{\circ} \mathrm{C}$ depending on the conditions involved as in an agreement by Boonstra and Tjeerdsma[12] which stated that different process conditions and treatment time applied during heat treatment can influence degradation rate of cellulose content. Fengel and Wegener[15] found that the degree of polymerization of cellulose is already decreased in thermally treated spruce at temperatures above $120^{\circ} \mathrm{C}$ due to cleavage of the glucosidic bonding that is accelerated by the presence of acids that are catalyzing the reaction. With extended heating, chain scission of the cellulose occurs, producing alkaline soluble oligosaccharides, with a concomitant decrease in the cellulose DP and degree of cyrstallinity [10]. $\mathrm{CO}_{2}$ and $\mathrm{CO}$ are produced when cellulose is heated at $170^{\circ} \mathrm{C}$ [16] and heating for a longer periods results in an increase in carbonyl groups at the expense of carboxylic moieties [15].

Hemicellulose: Hemicelluloses content for both heat treated sapwood and heartwood showed fluctuation values, but with no specific trend. The hemicelluloses for sapwood experiences changes in content from $24.4 \%$ in control to $26.1 \%$ in heat treated samples. While in the heartwood the content changes from $24.5 \%$ to $26.2 \%$. Both wood experiences an increases in the hemicelluloses contents. Mburu et al. [17] found that the increment in lignin content of Grevillea robusta wood with treatment time confirming higher susceptibility of hemicelluloses to thermal treatment. Rowell et al.[18], stated that hemicelluloses change is predominate at temperatures below $200^{\circ} \mathrm{C}$. The lower thermal stability of hemicellulose compared to cellulose is usually explained by the lack of crystallinity [19], When wood is heated, the most thermally labile of the hemicelluloses begin to degrade, resulting in the production of methanol, acetic acid and various volatile heterocyclic compounds [10]. The acetic acid is generated when the acetylated hydroxyl groups of the hemicellulose chains are split off [20]. It is suggested that volatile organic acids formed due to heating of wood are trapped in the process and promote the degradation rate [21].

Lignin: The lignin content of sapwood and heartwood in the $A$. hybrid increased with an increase in treatment temperature and duration. An increment in lignin content of the sapwood from $20.8 \%$ in the untreated wood to $24.7 \%$ in the heat treated wood, while the lignin content of the 
heartwood from $22.4 \%$ in the untreated heartwood to $25.0 \%$ in the heat treated wood. Similar observations were also made by Brito et al. [22], Mburu et al. [17], Inari et al. [11], Yildiz et al. [14] and Sarni et al. [23]. The changed in lignin composition showed that there was a changed in the lignin structure of wood. The loss of polysaccharides material during the heat treatment leads to an increase in the lignin content of the wood [24].

\section{Analysis of Variance on Chemical Composition}

The ANOVA (Table 5) showed that there was a significant difference between the temperatures and duration of the treatment relating to content of lignin. Almost all of the chemical components were significantly affected by temperature, treatment duration and wood types. There were a significant difference between the treatment temperature, duration and wood type of the treatment relating to the content of holocellulose, cellulose and lignin. Therefore, it can be concluded that the effects of temperature, treatment duration and wood types were a caused of the change in chemical composition of those chemical component. For the hemicellulose, the ANOVA showed that there was no significant difference with wood type of the treatment relating to the content of hemicellulose. The wood types did not affect the changed in hemicellulose content in oil thermally modified process. The effects of temperature and treatment duration were a cause of decrement of hemicellulose composition. The changes in the chemical content of the wood increases with the increases in temperature. The chemical composition in $A$. hybrid wood is highly affected by treatment temperature, duration and wood types in oil thermally modified process.

\section{Colour Changes}

Table 2 presents the colour changed values of treated sapwood and heartwood. Based on the colour measurement of both the sapwood and heartwood, the effect on colour through oil heat treatment can be readily observed at different treatment temperature and treatment time, compared to the original color of the specimen.

\section{Lightness $\left(\mathrm{L}^{*}\right)$ of Wood Colour}

In this study the main involvement of the changed in colour of both wood types is the lightness $\left(\mathrm{L}^{*}\right)$. The variation in $\mathrm{L}^{*}$ ha as more responsive sign of colour change to the human eye that accompanying change in chromic characters $\mathrm{a}^{*}$ and $\mathrm{b}^{*}$, Thulasidas et $a .^{25}$ reported that the variability in darkness or lightness is the main cause of wood colour variability.

From the changed in lightness $\left(\mathrm{L}^{*}\right)$ values, both sapwood and heartwood showed decrease in lightness in the first 30 minutes of every treatment and it becomes progressively decreased with the increase of treatment temperature and duration. However the $\mathrm{L}^{*}$ values of heartwood did not changed considerably if compared to $\mathrm{L}^{*}$ values of sapwood. This might be because of the brightness of the wood colour itself as the sapwood of acacia has a brighter colour than heartwood.

From the observation, sapwood becomes slightly darker, while heartwood becomes considerably darker when exposed to vary treatment conditions. From the result obtained from bottom, middle and top portion of sapwood, wood treated at $220^{\circ} \mathrm{C}$ in 30 minutes showed $\mathrm{L}^{*}$ values almost have similar values with $\mathrm{L}^{*}$ values of untreated heartwood. This also can be observed obviously from the below figure shown.

From the result shown, the decreased in $\mathrm{L}^{*}$ values between $200^{\circ} \mathrm{C}-220^{\circ} \mathrm{C}$ was larger than $180^{\circ} \mathrm{C}$ in sapwood if compared to heartwood. The $\mathrm{L}^{*}$ values in heartwood slightly changed when the temperature exceed $200^{\circ} \mathrm{C}$. The largest changed of treatment duration of both wood types can be found between 60 - 90 minutes. This indicates the changed in $\mathrm{L}^{*}$ values gradually decreased with the increased of treatment temperature and time.

The summary of correlation coefficient of colour variation with other wood properties of treated acacia is given in Table 4 . There was a correlation between $\mathrm{L}^{*}$ and chemical component of acacia wood. Positive correlations were observed between $\mathrm{L}^{*}$ and holocellulose and cellulose. While hemicellulose and lignin were negatively correlated with colour. The conclusion is that the changed in wood colour were influenced by the chemical components of the wood. According to Sundqvist [13], the differences of chemical composition in wood such as extractive and lignin in sapwood and heartwood can probably be the main reason for dissimilar in colour. This reinforced by the research done by Burtin et al. [26] where during steaming at elevated temperatures, polyphenols compounds found in hybrid walnut heartwood which conferred the dark color to heartwood, may migrate in the sapwood region and change the sapwood colour from light to dark changes in wood colour.

Mitsui et al. [27] and Bourgios et al. [28] also reported that decreased in lightness was resulting from high temperature of heat treatment due to decrement in certain chemical component in wood such as hemicelluloses and lignin. Changes in wood colour can be an indication of chemical modification or changes in wood [26, 29, 13].

\section{Chroma Colour, $\mathrm{a}^{*}$ (Reddish Colour)}

In the chroma coordinates, $\mathrm{a}^{*}$ and $\mathrm{b}^{*}$ are a combination of red $\left(a^{*}\right)$ and yellow $\left(b^{*}\right)$. Both of the wood types samples showed some differences due to changes in $a^{*}$ and $b^{*}$ values. The $a^{*}$ values of sapwood was increased while $a^{*}$ values of heartwood decreased through this treatment. This might be because of the original colour of the wood samples itself. Original sapwood colour of $A$. hybrid is light yellowish red while heartwood colour is brownish red. Increased in treatment temperature tends to increase the $\mathrm{a}^{*}$ values of sapwood. The $\mathrm{a}^{*}$ values reaches a maximum values after treated at $220^{\circ} \mathrm{C}$ temperature. Based on the a* values, the colour of sapwood becomes more red than before while red colour in heartwood becomes lessen. According to Hon et al. [30] the reddish colour and increased saturation substantiated as a decrease in hue and increase in chroma can be due to the formation of secondary condensation or degradation products of the quinine and quinonemethide types.

There was a correlation between $\mathrm{a}^{*}$ and chemical component of acacia wood (Table 4). Positive correlations were observed between $a^{*}$ and $b^{*}$, holocellulose, cellulose and lignin. While hemicellulose (were negatively correlated with $a^{*}$. However $a^{*}$ did not significant correlated with all chemical component except for lignin. According to Charrier 
et al. [31] and Grelier et al. [32[, wood colours changed from yellow to brown because of the photo-oxidation of lignin and wood extractives, with the production of coloured quinines component.

\section{Chroma Colour, $\mathrm{b}^{*}$ (Yellowish Colour)}

The $b^{*}$ values of heartwood shows the negative change from the start of the treatment. This means that the yellowish colour in heartwood start to decrease from $180^{\circ} \mathrm{C}$ and it decreases drastically when exposed to $220^{\circ} \mathrm{C}$ and longer treatment duration. There was a correlation between $b^{*}$ and $\mathrm{a}^{*}$ of $A$. hybrid wood (Table 4). Positive correlations were observed between $a^{*}$ and $b^{*}$. Besides $a^{*}, b^{*}$ did not significantly correlated with other wood properties in this study.

\section{Strength Properties (MOR and MOE in Bending Tests)}

The result of strength properties of treated $A$. hybrid wood is presented in Table 3. It is clearly observed the values of both wood types (sapwood and heartwood) for modulus of rupture (MOR) and modulus of elasticity (MOE) decreased through oil thermally modified. The untreated wood still obtained the highest strength values compared to treated wood. The strength properties of wood usually decrease with increasing temperature and increase with decreasing temperature [33].

For the thermally modified wood, the highest values of MOR and MOE of every portion were starting to decreased when the treatment temperature reaching $180^{\circ} \mathrm{C}$. This strength values respectively decreased when treated at $200^{\circ} \mathrm{C}$ and $220^{\circ} \mathrm{C}$. From the results obtained the values of MOR and MOE of untreated and treated wood showed a decrement with increasing sampling height. The variations in MOR and MOE along the tree height can be explained by the decrease in maturity of wood and fibre length from the base to the top of the tree [34].

According to Giebeler [35], wood treated at 180 to $200^{\circ} \mathrm{C}$ in the presence of moisture resulted in a large reduction in the resistance to MOR, MOE and compression strength. While other researcher reported that at temperature over $200^{\circ} \mathrm{C}$, MOE and MOR of wood can be reduced by up to $50 \%[29,36,37]$. The increased treatment duration which is 30 to 90 minutes also prolong the decreasing effect on strength. This testifies a value of MOR for treated wood is influenced by treatment temperature and duration. The higher the temperature the longer the treatment duration the lower is the strength value. However MOE did not show significantly difference with treatment duration and this is reinforced by the ANOVA in Tables 4 and 7.

The strength properties of the oil heat treated wood are reduced by thermal modification but the dimensional stability and biological durability of wood is increased without have to add outside chemicals to the wood [14]. The diminutions in the strength properties were related to the rate of thermal degradation and losses of substances after heat treatment [38]. The decrease in strength mainly due to the depolymerization reactions of wood polymers [19], where changes in or loss of hemicelluloses play key roles in the strength properties of wood heated at high temperatures [39]. Kocaefe et al. [40] also noted that the change in mechanical properties of wood especially in strength at high temperature is mainly due to the hemicelluloses degradation. It has a lower molecule weight compared to the other wood polymers, therefore it degrades faster. Thus, the cellulose crystallization and lignin modification take place [41].

Kocaefe et al. [40] noted that higher temperatures have negative effect on degradation consequently on the strength properties. According to Stamm [42], heat treatment affected lignin and hemicelluloses and resulted in water soluble polymer formation. The moisture content, treatment temperature, presence and absence of oxygen and treatment time are the factors, which influence most the hydrolysis reactions, consequently the mechanical properties. However, the effects on strength decreases are different for each species, anatomical features and treatment methods $[17,40]$.

Bekhta and Niemz [29], studied the effect of high temperature on spruce wood found that MOE of spruce wood decrease when the treatment temperature rose over $100^{\circ} \mathrm{C}$. Sundqvist [13] reported that at lower temperatures up to approximately $100^{\circ} \mathrm{C}$, only minor changes occur in the mechanical properties of wood however strength properties of wood start to weaken and becomes brittle when treatment temperatures reach over $200^{\circ} \mathrm{C}$. Nordahlia [43] and Bodig and Jayne [44] reported that compression failure typically occurs in low density wood. The reduction of density in the treated material can caused reduction in some of the strength properties [45, 46]. Strength loss increases with increased treatment temperature and time. Hence the use of heattreated wood in load bearing constructions is restricted due to bending and tension strength decrease by 10 to $30 \%$ [47, 48].

\section{Analysis of Variance on the Strength Properties}

The analysis of variance for the strength properties are shown in Tables 7 . The analysis was conducted to determine whether there was significance difference between physical properties with treatment temperatures, duration, wood types and sampling height. There were significant difference between moisture content with treatment temperatures, duration and wood types. However there was no significant difference between moisture content and sampling height (bottoms towards the top) of the tree. For basic density, there were significant difference was observed with treatment temperatures, duration, wood types and sampling height.

The analysis of variance indicated that for MOR there are significant differences in treatment temperature, duration of treatment and sampling height. However, there is no significant difference in the wood type. For MOE, only two significant differences were observed, which are treatment temperature and wood types. There is no significant difference in duration of treatment and sampling height.

\section{Correlation Coefficient between the Chemical, Colour and Strength Properties}

The correlation among wood properties of $A$. hybrid wood is presented in Table 4. There was a correlation between moisture content and chemical composition of acacia wood. Positive correlations were observed between moisture content and holocellulose $(r=0.81)$ and cellulose $(r=0.82)$. While hemicellulose $(r=-0.40)$ and lignin $(r=-0.76)$ were negatively correlated with moisture content. According to Smith et al. [33], due to the existence of hydrogen bonding 
sites in hydroxyl groups present in cellulose, hemicellulose and lignin, wood is a hygroscopic material. From this treatment, dimensional stability is increased due to decrement in moisture. There was positive correlation between moisture content and basic density of acacia wood in this treatment, but the correlation was not significant. A similar result was observed by Nordahlia [43] in Azadirachta excelsa where moisture content and basic density was not correlated.

There was also a correlation between moisture content and strength properties in this study. Positive correlations were observed between moisture content and modulus of rupture $(\mathrm{r}=0.50)$ and modulus of elastic $(\mathrm{r}=0.40)$. Smith et al. [33] noted that wood contains five or six layers of attached water molecules when in the saturated condition. While only one layer of water molecules at moisture of about $6 \%$ which is directly attached to cells walls by hydrogen bonding in dried wood. Mechanical properties of wood may degrade when there is a change happen in this layer due to many new hydrogen bonds are generated in the microfibrils with removal water molecules from cell walls, resulting in an increase of crystalline regions. The correlation between the basic density and other wood properties are presented in Table 4 . There was a correlation between basic density and strength properties (MOR and MOE) and chemical composition of acacia wood. Positive correlations were observed between basic density and modulus of rupture $(\mathrm{r}=0.37)$, modulus of elasticity $(\mathrm{r}=$ $0.42)$, holocellulose $(r=0.24)$ and cellulose $(r=0.24)$.

The correlation between the strength properties and other wood properties are presented in Table 4. There were a correlation between MOR and MOE, physical properties, colour and chemical composition of treated wood. Positive correlation were obtained between MOR and MOE ( $\mathrm{r}=$ $0.60)$, moisture content $(\mathrm{r}=0.50)$, basic density $(\mathrm{r}=0.37)$, lightness $\left(\mathrm{L}^{*}\right)(\mathrm{r}=0.40)$, holocellulose $(\mathrm{r}=0.42)$ and cellulose $(r=0.42)$. While hemicellulose $(r=-0.19)$ and lignin $(r=-0.36)$ were negatively correlated with MOR. For MOE there were also a correlation between physical properties, colour and chemical composition of treated wood. Positive correlation were obtained between MOE and moisture content $(r=0.40)$, basic density $(r=0.42)$, lightness $(r=0.34)$, holocellulose $(r=0.35)$ and cellulose $(r$ $=0.37)$. While hemicellulose $(r=-0.24)$ and lignin $(r=-$ 0.31 ) were negatively correlated with MOE.

\section{CONCLUSIONS}

The hot oil thermal modification process caused some features changed in the chemical composition of $A$. hybrid wood. The degradation in holocellulose, cellulose, and hemicellulose contents was recognized when acacia woods were exposed to oil thermally modified process. Holocellulose and celulose degraded with the increasing of treatment temperature and time of heating exposure, while lignin showed the increment in content through this treatment.

The sapwood and heartwood of $A$. hybrid colour becomes darker once they are exposed to the high temperature and longer treatment time in the hot oil thermal modification process. The degree of the changes varies between both wood types. The sapwood tends to darken more than the heartwood. The increment in colour of both woods increases with temperature and treatment time. Treatment temperature at $200^{\circ} \mathrm{C}$ and treatment time of $90 \mathrm{~min}$. and $220^{\circ} \mathrm{C}$ at $30 \mathrm{~min}$. of the sapwood becomes uniform with the colour of the original untreated heartwood. The hot oil thermal modification process induced extensive darkening and reddening of $A$. hybrid wood.

For the strength properties of the oil heat treated $A$. hybrid wood, the values of both MOR and MOE decreased throughout the treatment process. The decreases in values were influenced by treatment temperature and duration. The value of MOR and MOE of the treated wood were influenced by the treatment temperature. The increase in the holocellulose and cellulose contents causes an increase in the strength (MOR and MOE) of the A. hybrid wood. On the other hand, the reduction of the hemicellulose and lignin contents causes the drop in strength of the hot oil treated $A$. hybrid.

\section{ACKNOWLEDGEMENT}

The research was financed by The Ministry of Science, Technology and Invention, Malaysia, under the Science Fund Project.

\section{REFERENCES}

[1] Razak, W., Aminuddin, M., Hashim, W.S. \& Othman, S. (2005) Effect of heat treatment using palm oil on properties and durability of Semantan bamboo. Journal of Bamboo and Rattan 4 (3): 211-220. ISSN: 1569-1568, International Network for Bamboo and Rattan.

[2] Bekhta, P. and Niemz, P. 2003. Effect of High Temperature on the Change in Color, Dimensional Stability and Mechanical Properties of Spruce Wood. Journal of Holzforschung. Vol. 57: 539-546.

[3] Hyvonen, A., Piltonen, P. and Niinimaki, J. 2006. Tall Oil/WaterEmulsions as Water Repellents for Scots Pine Sapwood. Journal of Holz als Roh-und Werkstoff. Vol 64: 68-73. DOI 10.1007/s00107005-0040-5.

[4] Technical Association of the Pulpa and Paper Industry. 1999. TAPPI Standard T203 om-99. Atlanta, USA.

[5] Technical Association of the Pulpa and Paper Industry. 2002. TAPPI Standard T222 om-02. Atlanta, USA.

[6] Unsal, O., Korkut, S. and Atik, C. 2003. The effect of heat treatment on some properties and colour in Eucalyptus (Eucalyptus camaldulensis DEHN.) wood. Journal of Maderas. Ciencia Technologia. 5(2):145-152.

[7] CIE (Commission Internationale De Eclairage). 1986. Publication 15.2. Colorimetry, Second Edition Central Bureau of the CIE. Viena, Austria.

[8] American Society for Testing and Material. 1999. ASTM D4761-05: Section 4: Construction. Volume 04.10: Wood. West Conshohocken,

[9] Izyan, K., Razak, W., Mahmud, S., Othman, S., Affendy, H., Hanim, R.A. \& Andy, R.M. (2010). Chemical Changes in 15 year-old Cultivated Acacia hybrid Oil-Heat Treated at 180,200 and $220^{\circ} \mathrm{C}$. International Journal of Chemistry 2 (1). Pp. 97-107. Feb. 2010. ISSN: 1916-9701. Canadian Center of Science and Education. Pennsylvania.

[10] Hill, C. 2006. Wood Modification: Chemical, Thermal and Other Processes. John Wiley \& Sons, Ltd. England. Hon, D. N. S. and Minemura,N. 1991. Color and Discoloration. In Hon, D. N. S. and Shirashi, N. (ed.) Wood and Cellulosic Chemistry,pp.395-454. New York: Marcel Dekker Inc.

[11] Inari, G. N., Petrissans, M. and Gerardin, P. 2007. Chemical Reactivity of Heat-treated Wood. Journal of Wood Science and Technology. 41: 157-168.

[12] Boonstra, M. J. and Tjeerdsma, B. 2005. Chemical Analysis of Heat Treated Softwoods. European Journal of Wood and Wood Products. Vol. 64, No. 3, 204-211. DOI: 10.1007/s00107-005-0078-4. 
[13] Sundqvist, B. 2004. Colour Changes and Acid Formation in Wood during Heating. Ph.D. Thesis. Lulea University of Technology.

[14] Yildiz, S., Gezer, E. D. \& Yildiz, U. C. 2006. Mechanical and Chemical Behaviour of Spruce Wood Modified by Heat. Journal of Building and Environment. 41:1762-1766.

[15] Fengel, D. and Wegener, G. 1989. Wood Chemistry, Ultrastructure, Reactions.Walter de Gruyter and Co. Berlin, New York.

[16] Shafizadeh, F. 1984. The Chemistry of Pyrolysis and Combustion. In The Chemistry of Solid Wood, Rowell, R.M. (Ed). ACS Symposium Series, 207, pp. 489-529.

[17] Mburu, F., Dumarcay, S., Bocquet, J.F., Petrissans, M. \& Gerardin, P. 2008. Effect of Chemical Modifications Caused by Heat Treatment on Mechanical Properties of Grevillea robusta Wood. Journal of Polymer Degradation and Stability. 93: 401-405. DOI: 10.1016/j.polymdegradstab. 2007.11.017.

[18] Rowell, R. M., Pettersen, R., Han, J. S., Rowell, J. S. \& Tshabalala, M. A. 2005. Cell Wall Chemistry. In Rowell R.M. (ed.). Handbook of Wood Chemistry and Wood Composites, pp. 37-72. Madison: CRC Press.

[19] Kotilainen, R. 2000. Chemical Changes in Wood During Heating at $150^{\circ} \mathrm{C}-260^{\circ} \mathrm{C}$. Ph.D Thesis. Jyvaskyla University, Finland.

[20] Johansson, D. 2008. Heat Treatment of Solid Wood; Effects on Absorption, Strenght and Colour. Ph.D. Thesis. Lulea University of Technology. ISSN: 1402-1544.

[21] Viitaniemi, P. 2001. The Thermal Modification of Wood with Heat Treatment. VTT Building and Transport, pp. 1-21, Espoo, Findland.

[22] Brito, J. O., Silva, F. G., Leao, M.M \& Almeida, G. 2008. Chemical Composition Changes In Eucalyptus and Pinus Woods Submitted to Heat Treatment. Journal of Bioresource Technology. Vol. 99, Issue 18, Dec. 2008. Pp 8545-8548. DOI 10.1016/j.biortech. 2008.03.069.

[23] Sarni, F., Moutounet, M., Puech, J. L. \& Rabier, P. 1990. Effect of Heat Treatment on Oak Wood Extractable Compounds. Journal of Holzforschung. 44(6): 461-466.

[24] Sandermann, W. \& Augustin, H. 1964. Chemical Investigations on the Thermal Decomposition of Wood. Part III: Chemical Investigation on the Course of Decomposition. Journal of Holz als Roh-und Werkstoff. 22(10): 377-386.

[25] Thulasidas, P.K., Bhat, K.M. and Okuyama, T. 2006. Heartwood colour variation in home garden teak (Tectona grandis) from wet and dry localities of Kerala India. Journal of Tropical Forest Science. 18:51-54

[26] Burti, P., Jay-Allemand, C., Charpentier, J. P. and JANIN, G. 1998 Natural Wood Colouring Process in Juglans Spp. (J.nigra, J.regia, and Hybrid J. nigra x J. regia) Depends on Native Phenolic Compounds Accumulated in the Transition Zone between Sapwood and Heartwood. Journal of Trees. 12:258-264.

[27] Mitsui, K., Takada, H., SUGIYAMA, M. and Hasegawa, R. 2001. Changes in the Properties of Light-Irradiated Wood with Heat Treatment. Part 1. Effect of Treatment Conditions on the Change in Color. Journal of Holzforschung. Vol 55: 601-605.

[28] Bourgois, P.J., Janin, G. and Guyonnet, R. 1991. La Mesure de Couleur. Une Methode d'Etude et d' Optimisation des Transformations Chimiques du Bois Thermolyse. Journal of Holzforchung. Vol 45:377-382.

[29] Izyan, K., Razak, W., Othman, S., Aminuddin, M., Hanim, R.A., Tamer, A.T., Affendy, H. (2010). Enhancing colour appearances of cultivated 15 year-old Acacia hybrid through oil heat treatment process. International Journal of Biology 2 (2). Pp 199-209. ISSN: 1916-9671. Canadian Center of Science and Education.

[30] Hon, D. N. S. and Minemura,N. 1991. Color and Discoloration. In Hon, D. N. S. and Shirashi, N. (ed.) Wood and Cellulosic Chemistry,pp.395-454. New York: Marcel Dekker Inc.
[31] Charrier, B., Charrier, F., Janin, G., Kamdem, D.P., Irmouli, M. and Goncalez, J. 2002. Study of Industrial Boiling Process on Walnut Colour: Experimental Study Under Industrial Conditions. Journal of Holz als Roh-und Werkstoff. Vol 60: 259-264. DOI 10.1007/s00107005-0082-8.

[32] Grelier, S., Castellan, A., Desrousseaux, S., Nour, A., Ode, A. and Podgorski, L. 1997. Attempt to Protect Wood Colour Against UV/Visible Light by Using Antioxidants Bearing Isocyanate Groups and Grafted to the Material with Microwave. Journal of Holzforschung. 51: 511-518.

[33] Smith, I., Landis, E. \& Gong, M. 2003. Structure and Properties of Wood. In Fracture and Fatigue in Wood, pp.7-34. Chichester: John Wiley \& Sons Ltd.

[34] Rulliarty, S. \& America, W. A.1995. Natural Variation in Wood Quality Indicators of Indonesian Big Leaf Mahogany(Swietenia macrophylla. King). XX IUFRO World Congress Proceedings, Tampere.

[35] Giebeler, E. 1983. Dimensional Stabilization of Wood by Moistureheat-pressure. Journal of Holz als Roh-und Werkstoff. 41: 87-94.

[36] Sailer, M., Rapp, A. O., Leithoff, H. \& Peek. R.D. 2000. Improved Resistance of Scots Pine by Application of an Oil thermally modified. European Journal of Wood and Wood Products. Vol. 58, Numbers 1-2, 15-22. DOI: 10.1007/s001070050379.

[37] Kamden, D. P., Pizzi, A., Guyonnet, R. \& Jermannaud, A. 1999 Durability of Heat-treated Wood. IRG WP: International Research Group on Wood Preservation 30. Rosenheim, Germany. 6-1 $11^{\text {th }}$ June 1999.

[38] Rushe, H. 1973. Thermal Degradation of Wood at Temperatures up to $200^{\circ}$ C.I. Strenght Properties of Wood After Heat Treatment. Journal of Holz als Roh-und Werkstoff. 31(7): 273-281.

[39] Hillis, W. E. 1984. High Temperature and Chemical Effects on Wood Stability. Part 1: General Considerations. Journal of Wood Science and Technology. 18:281-293.

[40] Kocaefe, D., Chaudry, B., Ponscak, S., Bouazara, M. \& Pichette, A. 2007. Thermogravimetric Study of High Temperature Treatment of Aspen: Effect of Treatment Parameters on Weight Loss and Mechanical Properties. Journal of Material Science. 42: 854-866.

[41] Wikberg, H. \& Maunu, S.L. 2004. Characterization of thermally modified hardwoods and softwoods by 13C CPMAS NMR. Carbohydrate Polymers. 58:461-466.

[42] Stamm, A. J. 1964. Wood and Cellulose Science. The Ronald Press Co. New York.

[43] Nordahlia, A. S. 2008. Wood Quality of 10-Year-Old Sentang (Azadirachta excelsa) Grown from Seedlings and Rooted Cuttings. Master Thesis. University Putra Malaysia.

[44] Bodig, J. \& Jayne, B. A. 1982. Mechanics of Wood and Wood Composite. Van Nostrand Reinbold Co. New York, USA.

[45] Rafidah, S., Razak, W. \& Zaidon, S. (2008). Effect of Oil thermally modified on Chemical Constituents of Semantan Bamboo (Gigantochloa scortechinii Gamble). Journal of Sustainable Development 1(2): 91-98. Canadian Center of Science and Education.

[46] Janssen, J. A. 1981. Bamboo in Building Structures. Ph.D. Thesis. University of Technology, Holland.

[47] Korkut, S., Kok, M.S., Korkut, D.S. \& Gurleyen, T. 2008. The Effects of Heat Treatment on Technological Properties in Red-Bud Maple (Acer trautvetteri Medw.). Journal of Bioresource Technology. Vol. 99 (6): 1538-1543. DOI 10.1016/ j.biortech. 2007. 04.021 .

[48] Jamsa, S. \& Viitaniemi, P.2001. Heat Treatment of Wood Better Durability Without Chemicals. Review on Heat Treatments of Wood. Cost Action E22. Proceedings of the Special Seminar, Antibes, France. Pp: 17-22. 
TABLE 1

AVERAGE VALUES OF CHEMICAL CHANGES OF 15-YEAR-OLD OIL HEAT-TREATED A. HYBRID WOOD

\begin{tabular}{|c|c|c|c|c|c|c|}
\hline \multirow{2}{*}{ Wood type } & \multirow{2}{*}{$\begin{array}{l}\text { Temp. } \\
\left({ }^{\circ} \mathrm{C}\right)\end{array}$} & \multirow{2}{*}{$\begin{array}{c}\text { Treatment } \\
\text { duration (min) }\end{array}$} & \multicolumn{4}{|c|}{ Chemical Composition (\%) } \\
\hline & & & Holocellulose & Cellulose & Hemicellulose & Lignin \\
\hline \multirow[t]{10}{*}{ Sapwood } & Control & Control & $71.5(0.00)$ & $47.1(0.00)$ & $24.4(0.00)$ & $20.8(0.00)$ \\
\hline & 180 & 30 & $70.8(-1.0)$ & $46.2(-1.9)$ & $24.6(0.8)$ & $20.7(-0.5)$ \\
\hline & & 60 & $69.7(-2.5)$ & $45.1 \quad(-4.2)$ & $24.6(0.8)$ & $22.0(5.8)$ \\
\hline & & 90 & $66.6(-6.9)$ & $43.6(-7.4$ & $23.0(-5.7)$ & $22.1(6.3)$ \\
\hline & 200 & 30 & $68.6(-4.1)$ & $42.5(-9.8)$ & $26.1(7.0)$ & $23.9(14.9)$ \\
\hline & & 60 & $65.3(-8.7)$ & $39.2(-16.8)$ & $26.0(6.6)$ & $23.8(14.4)$ \\
\hline & & 90 & $64.5(-9.8)$ & $38.5(-18.3)$ & $26.0(6.6)$ & $24.7(18.8)$ \\
\hline & 220 & 30 & $66.4(-7.1)$ & $41.6(-11.7)$ & $24.8(1.6)$ & $23.7(13.9)$ \\
\hline & & 60 & $64.9(-9.2)$ & $38.9(-17.4)$ & $26.0(6.6)$ & $24.3(16.8)$ \\
\hline & & 90 & $63.1(-11.7)$ & $37.7(-20.0)$ & $25.4(4.1)$ & $24.0(15.4)$ \\
\hline \multirow[t]{10}{*}{ Heartwood } & Control & Control & $73.4(0.00)$ & $48.9(0.00)$ & $24.5(0.00)$ & $22.4(0.00)$ \\
\hline & 180 & 30 & $71.7(-2.3)$ & $47.8(-2.3)$ & $23.9(-2.5)$ & $21.7(-3.1)$ \\
\hline & & 60 & $70.6(-3.8)$ & $46.3(-5.3)$ & $24.3(-0.8)$ & $22.9(2.2)$ \\
\hline & & 90 & $67.9(7.5)$ & $44.7(-8.6)$ & $23.2(-5.3)$ & 23.0 \\
\hline & 200 & 30 & $68.8(-6.3)$ & $42.6(-12.9)$ & $25.9(5.7)$ & $24.5(9.4)$ \\
\hline & & 60 & $68.3(-6.9)$ & $42.1(-14.0)$ & $26.2(6.9)$ & $24.9(11.2)$ \\
\hline & & 90 & $66.5(-9.4)$ & $40.9(-16.4)$ & $25.6(4.5)$ & $25.0(11.6)$ \\
\hline & 220 & 30 & $67.1(-8.6)$ & $42.0(-14.1)$ & $25.7(4.9)$ & $24.7(10.3)$ \\
\hline & & 60 & $65.1(-11.3)$ & $39.7(-18.8)$ & $25.4(3.7)$ & $24.8(10.7)$ \\
\hline & & 90 & $64.0(-12.8)$ & $38.1(-22.1)$ & $25.9(5.7)$ & $24.9(11.2)$ \\
\hline
\end{tabular}

( ) $=\%$ change from control,

Holocellulose is the total polysaccharide fraction of wood that is composed of cellulose and all of the hemicelluloses and what is obtained when the extractives and lignin are removed from the natural material.

TABLE 2

AVERAGE VALUES OF COLOUR VARIATION IN L*, A* AND B* OF OIL HEAT-TREATED A. HYBRID WOOD

\begin{tabular}{|c|c|c|c|c|c|c|c|c|c|c|c|}
\hline \multirow{2}{*}{$\begin{array}{r}\text { Wood } \\
\text { types }\end{array}$} & \multirow{2}{*}{$\begin{array}{r}\text { Temp. } \\
\left({ }^{\circ} \mathrm{C}\right) \\
\end{array}$} & \multirow{2}{*}{$\begin{array}{l}\text { Treatment duration } \\
\text { (min.) }\end{array}$} & \multicolumn{3}{|l|}{$\mathrm{L}^{*}$} & \multicolumn{3}{|l|}{$a^{*}$} & \multicolumn{3}{|l|}{$\mathrm{b}^{*}$} \\
\hline & & & $\mathrm{B}$ & $\mathrm{M}$ & $\mathrm{T}$ & $\mathrm{B}$ & $\mathrm{M}$ & $\mathrm{T}$ & $\mathrm{B}$ & $\mathrm{M}$ & $\mathrm{T}$ \\
\hline \multirow{11}{*}{ Sapwood } & Control & Control & 73.6 & 73.0 & 71.4 & 6.9 & 6.6 & 7.3 & 21.2 & 22.3 & 21.4 \\
\hline & \multirow{4}{*}{180} & 30 & 66.7 & 70.0 & 65.5 & 7.4 & 8.7 & 8.5 & 21.9 & 23.3 & 23.4 \\
\hline & & 60 & 65.4 & 62.7 & 63.0 & 8.8 & 9.9 & 9.8 & 25.7 & 26.3 & 24.1 \\
\hline & & 90 & 65.6 & 61.9 & 62.9 & 9.3 & 10.9 & 10.2 & 27.3 & 27.5 & 26.3 \\
\hline & & 30 & 63.5 & 63.5 & 58.2 & 9.5 & 10.0 & 9.9 & 26.4 & 26.1 & 26.2 \\
\hline & \multirow[t]{2}{*}{200} & 60 & 56.9 & 57.2 & 56.9 & 11.4 & 11.9 & 10.7 & 27.5 & 27.1 & 26.5 \\
\hline & & 90 & 50.7 & 54.6 & 51.6 & 12.2 & 12.4 & 12.2 & 27.9 & 28.9 & 28.0 \\
\hline & \multirow{3}{*}{220} & 30 & 56.5 & 53.0 & 53.4 & 11.7 & 10.6 & 10.3 & 27.6 & 26.9 & 26.7 \\
\hline & & 60 & 48.7 & 47.9 & 43.2 & 12.3 & 12.7 & 11.2 & 27.8 & 27.6 & 27.8 \\
\hline & & 90 & 41.5 & 40.6 & 39.2 & 13.9 & 13.5 & 12.6 & 28.1 & 29.3 & 28.9 \\
\hline & Control & Control & 54.1 & 54.8 & 53.5 & 14.2 & 15.1 & 13.9 & 26.8 & 26.3 & 25.2 \\
\hline \multirow{9}{*}{ Heartwood } & \multirow{3}{*}{180} & 30 & 53.6 & 52.7 & 52.9 & 13.4 & 12.9 & 12.0 & 25.0 & 24.8 & 24.1 \\
\hline & & 60 & 51.7 & 51.6 & 50.7 & 11.9 & 11.1 & 11.5 & 23.6 & 23.2 & 23.5 \\
\hline & & 90 & 50.4 & 50.2 & 48.2 & 11.2 & 10.8 & 10.7 & 23.0 & 21.5 & 22.3 \\
\hline & \multirow{3}{*}{200} & 30 & 51.4 & 52.1 & 48.6 & 11.5 & 10.3 & 11.3 & 23.7 & 24.1 & 23.9 \\
\hline & & 60 & 49.1 & 50.5 & 46.9 & 11.0 & 9.7 & 10.7 & 23.4 & 21.5 & 21.9 \\
\hline & & 90 & 45.9 & 46.7 & 43.5 & 9.9 & 8.9 & 10.2 & 23.1 & 21.2 & 20.9 \\
\hline & \multirow{3}{*}{220} & 30 & 50.7 & 50.8 & 46.3 & 10.0 & 9.0 & 10.2 & 22.6 & 22.9 & 21.0 \\
\hline & & 60 & 46.6 & 47.4 & 38.8 & 8.3 & 8.3 & 8.4 & 21.1 & 19.8 & 17.2 \\
\hline & & 90 & 40.0 & 40.9 & 33.1 & 6.7 & 7.1 & 7.3 & 20.5 & 19.0 & 15.1 \\
\hline
\end{tabular}

Note: Temp. = temperature, $\mathrm{L}^{*}=$ lightness, $\mathrm{a}^{*}=$ red, $\mathrm{b}^{*}=$ yellow, $\mathrm{B}=$ Bottom, $\mathrm{M}=$ Middle, $\mathrm{T}=\mathrm{Top}$ 
TABLE 3

BENDING STRENGTH (MOR, MOE) OF SAP- AND HEARTWOOD A. HYBRID THROUGH HOT OIL-HEAT TREATMENT PROCESS

\begin{tabular}{|c|c|c|c|c|c|c|c|c|}
\hline \multirow[t]{2}{*}{ Wood Type } & \multirow{2}{*}{$\begin{array}{l}\text { Temp. } \\
\left({ }^{\circ} \mathrm{C}\right)\end{array}$} & \multirow{2}{*}{$\begin{array}{c}\text { Treatment } \\
\text { duration }(\mathrm{min})\end{array}$} & \multicolumn{3}{|c|}{$\operatorname{MOR}\left(\mathrm{N} / \mathrm{mm}^{2}\right)$} & \multicolumn{3}{|c|}{$\operatorname{MOE}\left(\mathrm{N} / \mathrm{mm}^{2}\right)$} \\
\hline & & & B & M & $\mathrm{T}$ & B & M & $\mathrm{T}$ \\
\hline \multirow[t]{19}{*}{ Sapwood } & Control & Control & 69.78 & 67.22 & 65.08 & 3864.54 & 3803.57 & 3776.72 \\
\hline & & 30 & 64.05 & 61.98 & 63.37 & 3535.7 & 3455.43 & 3492.52 \\
\hline & & 30 & $(8.21)$ & $(7.80)$ & $(2.63)$ & $(8.51)$ & $(9.15)$ & $(7.53)$ \\
\hline & & 60 & 63.43 & 59.66 & 52.23 & 3475.95 & 3416.45 & 3265.79 \\
\hline & 180 & 60 & (9.10) & (11.25) & (19.74) & (10.06) & (10.18) & (13.53) \\
\hline & & & 62.31 & 55.82 & 47.99 & 3470.29 & 3412.22 & 3207.16 \\
\hline & & 90 & $(10.71)$ & (16.96) & $(26.26)$ & $(10.20)$ & $(10.29)$ & $(15.08)$ \\
\hline & & & 55.06 & 54.85 & 45.31 & 3407.97 & 3328.01 & 3094.19 \\
\hline & & 30 & (11.64) & (18.40) & $(30.28)$ & (11.81) & $(12.50)$ & (18.07) \\
\hline & & & 60.11 & 54.70 & 44.86 & 3333.09 & 3228.98 & 3035.35 \\
\hline & 200 & 60 & (13.86) & (18.63) & (31.07) & (13.75) & (15.11) & (19.63) \\
\hline & & 00 & 55.38 & 50.41 & 42.85 & 3244.75 & 3172.19 & 2972.25 \\
\hline & & 90 & $(20.64)$ & (25.01) & $(34.16)$ & (16.04) & (16.60) & $(21.30)$ \\
\hline & & 30 & 53.9 & 49.72 & 40.57 & 3216.75 & 3101.06 & 2938.18 \\
\hline & & 30 & $(22.76)$ & (26.03) & (37.66) & (16.76) & (18.47) & $(22.20)$ \\
\hline & 230 & 60 & 51.42 & 46.89 & 38.15 & 3133.38 & 3046.50 & 2716.33 \\
\hline & 220 & 00 & $(26.31)$ & (30.14) & (41.38) & (18.92) & (19.90) & $(28.08)$ \\
\hline & & 00 & 41.21 & 40.33 & 37.03 & 3001.51 & 2787.39 & 2599.31 \\
\hline & & 90 & (40.94) & $(40.00)$ & (43.10) & $(22.33)$ & $(26.72)$ & (31.18) \\
\hline \multirow[t]{19}{*}{ Heartwood } & Control & Control & 68.51 & 70.76 & 90.43 & 3975.49 & 4004.07 & 4067.94 \\
\hline & & 30 & 67.42 & 65.24 & 66.70 & 3676.91 & 3637.29 & 3721.56 \\
\hline & & 30 & (1.59) & $(7.80)$ & (26.24) & (7.51) & $(9.16)$ & $(8.51)$ \\
\hline & & 60 & 66.77 & 63.47 & 54.98 & 3658.9 & 3634.52 & 3437.94 \\
\hline & 180 & 60 & (2.54) & (10.30) & $(39.20)$ & (7.96) & $(9.23)$ & (15.49) \\
\hline & & 00 & 65.59 & 58.81 & 51.06 & 3587.34 & 3599.88 & 3376.74 \\
\hline & & 90 & $(4.26)$ & (16.89) & (43.54) & (9.76) & (10.09) & (16.08) \\
\hline & & 30 & 63.27 & 58.75 & 47.74 & 3577.19 & 3547.83 & 3291.87 \\
\hline & & 30 & (7.65) & (16.97) & $(47.21)$ & (10.02) & (11.39) & (19.08) \\
\hline & & & 58.8 & 57.74 & 47.7 & 3545.84 & 3503.17 & 3229.33 \\
\hline & 200 & 60 & $(14.17)$ & (18.40) & $(47.25)$ & $(10.81)$ & $(12.51)$ & $(20.62)$ \\
\hline & & 90 & 58.57 & 53.63 & 45.67 & 3488.98 & 3435.31 & 3162.30 \\
\hline & & 90 & (14.51) & $(24.21)$ & (49.50) & (12.24) & $(14.20)$ & $(22.26)$ \\
\hline & & & 57.96 & 52.89 & 43.62 & 3422.08 & 3299.28 & 3159.49 \\
\hline & & 30 & $(15.40)$ & $(25.25)$ & (51.76) & (13.92) & $(17.60)$ & $(22.33)$ \\
\hline & 220 & 60 & 55.30 & 50.42 & 41.02 & 3369.22 & 3275.80 & 2920.83 \\
\hline & 220 & 60 & (19.28) & (28.75) & $(54.6()$ & $(15.25)$ & (18.19) & $(28.20)$ \\
\hline & & 90 & 44.31 & 44.7 & 39.81 & 2997.64 & 3227.43 & 2794.95 \\
\hline & & 90 & $(35.32)$ & (36.83) & (55.98) & (24.60) & (19.40) & $(31.29)$ \\
\hline
\end{tabular}

Note: $($ ) $=\%$ change from control samples, $\mathrm{B}=$ Bottom, $\mathrm{M}=$ Middle, $\mathrm{T}=\mathrm{Top}$

TABLE 4

CORRELATIONS BETWEEN MECHANICAL, COLOUR AND CHEMICAL PROPERTIES OF 15 YEAR-OLD CULTIVATED A. HYBRID

\begin{tabular}{|c|c|c|c|c|c|c|c|c|c|}
\hline $\begin{array}{l}\text { Wood } \\
\text { Properties }\end{array}$ & MOR & MOE & $\mathrm{L}^{*}$ & $a^{*}$ & $b^{*}$ & Holo & Hemi & Cell & Lignin \\
\hline MOR & 1.00 & $0.60 * *$ & $0.40 * *$ & $-0.06 \mathrm{~ns}$ & $0.02 \mathrm{~ns}$ & $0.42 * *$ & $-0.19 *$ & $0.42 * *$ & $-0.36 * *$ \\
\hline MOE & & 1.00 & $0.34 * *$ & $0.05 \mathrm{~ns}$ & $-0.01 \mathrm{~ns}$ & $0.35 * *$ & $-0.24 * *$ & $0.37 * *$ & $-0.31 * *$ \\
\hline $\mathrm{L}^{*}$ & & & 1.00 & $-0.37 * *$ & $0.11 \mathrm{~ns}$ & $0.51 * *$ & $-0.33 * *$ & $0.53 * *$ & $-0.75 * *$ \\
\hline$a^{*}$ & & & & 1.00 & $0.47 * *$ & $0.11 \mathrm{~ns}$ & $-0.02 \mathrm{~ns}$ & $0.10 \mathrm{~ns}$ & $0.15^{*}$ \\
\hline$b^{*}$ & & & & & 1.00 & $-0.07 \mathrm{~ns}$ & $-0.07 \mathrm{~ns}$ & $-0.04 \mathrm{~ns}$ & $-0.01 \mathrm{~ns}$ \\
\hline Holo & & & & & & 1.00 & $-0.34 * *$ & $0.96 * *$ & $-0.69 * *$ \\
\hline Hemi & & & & & & & 1.00 & $-0.59 * *$ & $0.61 * *$ \\
\hline Cell & & & & & & & & 1.00 & $-0.77 * *$ \\
\hline Lignin & & & & & & & & & 1.00 \\
\hline
\end{tabular}


TABLE 5

ANOVA ON CHEMICAL COMPOSITIONS OF OIL HEAT TREATED 15 YEAR-OLD ACACIA HYBRID

\begin{tabular}{|l|l|r|r|r|r|}
\hline Source of Variance & Dependent Variable & Sum of Squares & Df & Mean Square & F-Ratio \\
\hline \multirow{4}{*}{ Temperature } & Holocellulose & 1618.96 & 3 & 539.65 & $564.15^{* *}$ \\
& Hemicellulose & 139.12 & 3 & 46.37 & $85.82^{* *}$ \\
& Cellulose & 2460.23 & 3 & 820.08 & $1018.75^{* *}$ \\
& Lignin & 368.90 & 3 & 122.97 & $461.45^{* *}$ \\
Duration & Holocellulose & 250.82 & 2 & 125.41 & $131.10^{* *}$ \\
& Hemicellulose & 7.43 & 2 & 3.72 & $6.88^{* *}$ \\
Wood types & Cellulose & 210.26 & 2 & 105.13 & $130.60^{* *}$ \\
(Sap and & Lignin & 12.69 & 2 & 6.35 & $23.81^{* *}$ \\
Heartwood) & Holocellulose & 96.80 & 1 & 96.80 & $101.20^{* *}$ \\
& Hemicellulose & 0.01 & 1 & 0.01 & $0.01 \mathrm{~ns}$ \\
& Cellulose & 95.20 & 1 & 95.20 & $118.27^{* *}$ \\
& Lignin & 52.22 & 1 & 52.22 & $195.94^{* *}$ \\
\hline
\end{tabular}

TABLE 6

ANOVA OF COLOUR APPEARANCES OF TREATED A. HYBRID

\begin{tabular}{|c|c|r|r|r|r|}
\hline Source of Variance & Dependent Variable & Sum of Squares & Df & Mean Square & F-Ratio \\
\hline \multirow{3}{*}{ Temperature } & $\mathrm{L}^{*}$ & 9538.60 & 3 & 3179.53 & $110.70^{* *}$ \\
& $\mathrm{a}^{*}$ & 9.33 & 3 & 3.11 & $0.42 \mathrm{~ns}$ \\
Duration & $\mathrm{b}^{*}$ & 35.41 & 3 & 11.80 & $1.10 \mathrm{~ns}$ \\
& $\mathrm{~L}^{*}$ & 1257.57 & 2 & 628.79 & $21.89^{* *}$ \\
& $\mathrm{a}^{*}$ & 1.43 & 2 & 0.72 & $0.10 \mathrm{~ns}$ \\
Wood Types & $\mathrm{b}^{*}$ & 2.67 & 2 & 1.33 & $0.12 \mathrm{~ns}$ \\
(Sap and & $\mathrm{L}^{*}$ & 6537.30 & 1 & 6537.30 & $227.60^{* *}$ \\
Heartwood) & $\mathrm{a}^{*}$ & 94.80 & 1 & 94.80 & $12.82^{* *}$ \\
Sampling Height & $\mathrm{b}^{*}$ & 294.70 & 1 & 294.70 & $27.55^{* *}$ \\
& $\mathrm{~L}^{*}$ & 222.61 & 2 & 111.31 & $3.88^{*}$ \\
& $\mathrm{a}^{*}$ & 0.78 & 2 & 0.39 & $0.05 \mathrm{~ns}$ \\
& $\mathrm{~b}^{*}$ & 23.77 & 2 & 11.89 & $1.11 \mathrm{~ns}$ \\
\hline
\end{tabular}

TABLE 7

ANOVA ON THE STRENGTH PROPERTIES OF OIL HEAT TREATED A. HYBRID

\begin{tabular}{|l|r|r|r|r|r|}
\hline \multirow{2}{*}{ Source of Variance } & Dependent Variable & Sum of Squares & Df & Mean Square & F-Ratio \\
& & & & & \\
\hline Temperature & MOR & 12076.80 & 3 & 4025.59 & $15.99^{* *}$ \\
& MOE & 1.81 & 3 & 6.02 & $12.66^{* *}$ \\
Duration & MOR & 3425.40 & 2 & 1712.70 & $6.80^{* *}$ \\
& MOE & 2.72 & 2 & 1.36 & $2.86 \mathrm{~ns}$ \\
Wood Types & MOR & 565.80 & 1 & 565.80 & $2.25 \mathrm{~ns}$ \\
(Sap and Heartwood) & MOE & 2.16 & 1 & 2.16 & $4.55^{*}$ \\
Sampling Height & MOR & 3098.58 & 2 & 1549.29 & $6.15^{* *}$ \\
& MOE & 2.06 & 2 & 1.03 & $2.17 \mathrm{~ns}$ \\
\hline
\end{tabular}

$* *=$ significant at $\mathrm{p} \leq 0.01, *=$ significant at $\mathrm{p} \leq 0.05, \mathrm{~ns}=$ not significant, $\mathrm{MC}=$ Moisture Content,

$\mathrm{BD}=$ Basic Density, MOR= Modulus of Rupture, MOE = Modulus of Elasticity,

$\mathrm{L}^{*}=$ Lightness, $\mathrm{a}^{*}=$ Reddish, $\mathrm{b} *=$ Yellowish, Holo= Holocellulose, Hemi= Hemicellulose, Cell= Cellulose 